\section{'Solar Fire' Hybrid Tomato: Fla. 7776 Tomato Breeding Line}

\author{
J.W. Scott ${ }^{1}$ \\ Gulf Coast Research and Education Center, University of Florida, 14625 CR \\ 672, Wimauma, FL 33598
}

\section{S.M. Olson}

North Florida Research and Education Center, University of Florida, 155 Research Road, Quincy, FL 32351

\section{H.H. Bryan}

Tropical Research and Education Center, University of Florida, 18905 S.W. 280th St., Homestead, FL 33031

\section{J.A. Bartz}

Department of Plant Pathology, University of Florida, 1453 Fifield Hall, Gainesville, FL 32611

\section{D.N. Maynard}

Gulf Coast Research and Education Center, University of Florida, 14625 CR 672, Wimauma, FL 33598

\section{P.J. Stoffella}

Indian River Research and Education Center, University of Florida, 2199 S. Rock Rd., Ft. Pierce, FL 34945

Additional index words. Lycopersicon esculentum, heat-tolerance, Fusarium wilt race 3 , Solanum lycopersicum, vegetable breeding

Abstract. 'Solar Fire' is a heat-tolerant hybrid tomato (Solanum lycopersicum L. formerly Lycopersicon esculentum Mill.) with resistance to all three races of Fusarium wilt incited by Fusarium oxysporum f. sp. lycopersici Sacc. Snyder \& Hansen. It has superior fruitsetting ability in comparison with most existing cultivars under high temperatures $\left(>32{ }^{\circ} \mathrm{C}\right.$ day $/>21{ }^{\circ} \mathrm{C}$ night), and the fruit crack less under the rainy field conditions often present in the early fall Florida production season. Fla. 7776 is the pollen parent in 'Solar Fire', providing much of the heat tolerance in this hybrid. It has large fruit-providing breeders with a parent to produce heat-tolerant hybrids with two heat-tolerant parents.

\section{Origin}

'Solar Fire' is the $\mathrm{F}_{1}$ hybrid from the cross of Fla. 7946 (Scott, 2004) and Fla. 7776 (Fig. 1). It was tested as Fla. 7943B. Fla. 7946 provided Fusarium wilt race 3 resistance and a good level of fruit cracking resistance. Fla. 7946 does not set fruit well under hightemperature conditions, but it does seem to enhance the heat-tolerant fruit-setting ability of heat-tolerant parents such as Fla. 7776 in hybrid combinations. Fla. 7776 was the main source of heat-tolerant fruit setting, but it is only considered to be moderately heat tolerant from earlier testing (data not shown). It has large, globe-shaped fruit. The large fruit size in Fla. 7776 comes from 'Suncoast' (Scott et al., 1985) and Fla. 7060 (Fig. 1; Scott et al., 1989). Fla. 7418 was the main heat-tolerant

Received for publication 20 May 2005. Accepted for publication 22 May 2006. Florida Agricultural Expt. Sta. journal series no. R-10882.

${ }^{1}$ To whom reprint requests should be addressed; e-mail jwsc@ufl.edu.

\section{Description}

'Solar Fire' has a medium-size, slightly open, determinate $(s p)$ vine with good fruit cover. The fruit are large (Tables 1 and 2), flat-round, smooth, firm (Table 3), have lightgreen shoulders, and ripen to a good red color (Table 3). The light-green shoulder color could be the result of the $u g$ or the $u$ gene. The distinction of these genes is generally not obvious to the tomato-breeding community, and allelism tests have been lacking. The term light green is used here because the fruit shoulder is often slightly darker green than the rest of the fruit, whereas some genotypes have fruit with no difference between the shoulder and the rest of the fruit. The fruit maintain a regular symmetrical shape and blossom scars are smooth. Fla. 7776 has the $n-2$ gene (Barten et al., 1994), so the hybrid is heterozygous for this nipple tip gene. Fla. 7946 does not have a nipple blossom scar gene but has smooth blossom scars under a range of growing conditions. The fruit crack less than many tomato cultivars currently grown in Florida. For instance, there was above average rainfall in the fall of 2002 at Bradenton $(30 \mathrm{~cm}$ in November and December before last harvest vs. the 40-year average of $11.6 \mathrm{~cm}$ for November and all of December) and the yield of 'Solar Fire' was relatively good in part because of the lack of cracking (Table 1). Also, the fruit showed less cracking after a $3.7-\mathrm{cm}$ rainfall just before the first harvest in the Quincy trial (Table 1; pers. obs., J. Scott). Maturity is early under hightemperature conditions (Table 1 ) and early to midseason under cooler conditions. Fruit flavor has been rated 3 on a scale from 1 (poor) to 5 (excellent) by J.W.S. For comparison, an earlier heat-tolerant hybrid released from this program 'Solar Set' would rate a 4 on this scale.

Fla. 7776 has a medium-size determinate vine with good fruit cover. Fruit are globe shaped and large with long pedicels. As with many globe shaped inbreds, the fruit size varies from small to large. The fruit can be prone to cuticle cracking, as is often the case with large-fruited types with this shape. Maturity is early under high temperatures and early-midseason under cooler conditions.

\section{Disease Resistance}

'Solar Fire' is resistant to races 1, 2, and 3 of Fusarium wilt $(I, I-2, I-3)$, Verticillium

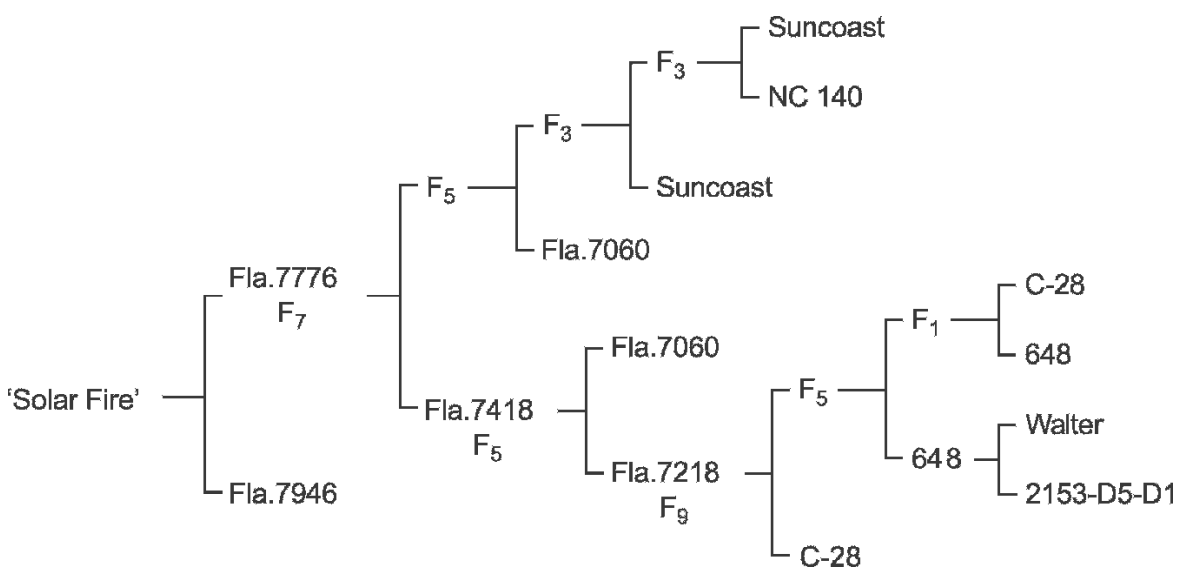

Fig. 1. Pedigree of 'Solar Fire' hybrid tomato and Fla. 7776 breeding line. 
Table 1. Marketable yield and fruit size for tomato genotypes under high temperature conditions in north (Quincy) and west central (Bradenton) Florida in the fall of 2002.

\begin{tabular}{|c|c|c|c|c|c|c|c|c|}
\hline \multirow[b]{3}{*}{ Genotype } & \multicolumn{3}{|c|}{ Quincy, Fla. } & \multicolumn{5}{|c|}{ Bradenton, Fla. } \\
\hline & \multicolumn{2}{|c|}{$\begin{array}{c}\text { Marketable yield } \\
\left(11.3 \mathrm{~kg} \text { cartons } \cdot \mathrm{ha}^{-1}\right) \\
\end{array}$} & \multirow{2}{*}{$\begin{array}{l}\text { Fruit size } \\
\qquad(\mathrm{g})\end{array}$} & \multicolumn{2}{|c|}{$\begin{array}{l}\text { Early marketable yield } \\
\left(11.3 \mathrm{~kg} \text { cartons } \cdot \mathrm{ha}^{-1}\right)\end{array}$} & \multicolumn{2}{|c|}{$\begin{array}{c}\text { Total season marketable } \\
\text { yield }\left(11.3 \mathrm{~kg} \text { cartons } \cdot \mathrm{ha}^{-1}\right)\end{array}$} & \multirow{2}{*}{$\begin{array}{l}\text { Fruit size } \\
\text { (g) }\end{array}$} \\
\hline & Total & Extra large & & Total & Extra large & Total & Extra large & \\
\hline Solar Fire & $1841 \mathrm{a}^{\mathrm{z}}$ & $1297 \mathrm{a}$ & $183 \mathrm{a}$ & $1215 \mathrm{a}$ & $1070 \mathrm{a}$ & $1660 \mathrm{a}$ & $1385 \mathrm{a}$ & $187 \mathrm{ab}$ \\
\hline Solar Set & $1568 \mathrm{~b}$ & 896 b & $159 \mathrm{~b}$ & $830 \mathrm{~b}$ & $683 \mathrm{~b}$ & $1639 \mathrm{a}$ & $1217 \mathrm{ab}$ & $176 \mathrm{~b}$ \\
\hline Florida 47 & $1370 \mathrm{bc}$ & $821 \mathrm{~b}$ & $163 \mathrm{~b}$ & $482 \mathrm{c}$ & $397 \mathrm{c}$ & $1019 b$ & $818 \mathrm{~b}$ & $176 \mathrm{~b}$ \\
\hline Florida 91 & $1263 \mathrm{c}$ & $842 \mathrm{~b}$ & $173 \mathrm{ab}$ & $875 \mathrm{~b}$ & $793 \mathrm{~b}$ & $1466 \mathrm{ab}$ & $1274 \mathrm{a}$ & $196 \mathrm{a}$ \\
\hline
\end{tabular}

${ }^{z}$ Mean separation within columns by Duncan's multiple range test at $P \leq 0.05$.

Table 2. Marketable yield, fruit size, and culls for selected tomato genotypes in the spring of 2002 at Bradenton, Fla.

\begin{tabular}{lccc}
\hline & $\begin{array}{c}\text { Marketable } \\
\text { yield }(11.3 \mathrm{~kg} \\
\left.\text { cartons } \cdot \mathrm{ha}^{-1}\right)\end{array}$ & $\begin{array}{c}\text { Fruit } \\
\text { size } \\
(\mathrm{g})\end{array}$ & $\begin{array}{c}\text { Culls } \\
(\% \mathrm{by} \mathrm{wt})\end{array}$ \\
\hline Solar Fire & $4050 \mathrm{a}^{\mathrm{z}}$ & 189.7 & $10.4 \mathrm{c}$ \\
Floralina & $2958 \mathrm{ab}$ & 169.0 & $23.7 \mathrm{~b}$ \\
Sanibel & $2919 \mathrm{ab}$ & 190.5 & $37.7 \mathrm{ab}$ \\
Florida 47 & $2902 \mathrm{ab}$ & 185.4 & $39.0 \mathrm{ab}$ \\
Solar Set & $2706 \mathrm{~b}$ & 176.3 & $43.3 \mathrm{a}$ \\
& \multicolumn{4}{c}{ NS } \\
\hline
\end{tabular}

${ }^{\mathrm{z}}$ Mean separation in columns by Duncan's multiple range test at $P \leq 0.05$.

${ }^{y}$ Means in column not significantly different by Duncan's multiple range test at $P \leq 0.05$.

wilt race 1 incited by Verticillium dahliae Kleb. (Ve), and gray leafspot incited by Stemphyllium solani Weber $(\mathrm{Sm})$. It has moderate resistance to fruit bacterial soft rot (Erwinia carotovora subsp. carotovora) as indicated by its intermediate water uptake (Bartz, 1991; Table 4). In more recent testing, 'Solar Fire' has appeared to take up relatively less water, and thus it may have more tolerance than that indicated in Table 4 (Bartz and Scott, unpublished data). This hybrid has had more bacterial spot (Xanthomonas campestris pv. vesicatoria) than some cultivars grown in Florida, and this likely has come from primarily from Fla. 7946, because Fla. 7776 is not as susceptible as the former. However, fruit set has been good despite this in most cases (Scott, pers. obs.). 'Solar Fire' is tolerant to common fruit disorders. Zippering seems to be the most common disorder. There has been some symptoms of blotchy ripening, blossom-end rot, and graywall under some conditions, but expression of these has not been serious compared with most currently grown cultivars in Florida.

Fla. 7776 is resistant to Fusarium wilt races 1 and 2, Verticillium wilt race 1 , and gray leafspot. Fla. 7776 has low stem scar

Table 3. Firmness and fruit color for selected tomato genotypes in the fall of 2002 at Bradenton, Fla.

\begin{tabular}{|c|c|c|c|c|c|}
\hline \multirow[b]{2}{*}{ Genotype } & \multirow{2}{*}{$\begin{array}{c}\text { Firmness }^{\mathrm{z}} \\
\text { (mm deformation) }\end{array}$} & \multicolumn{2}{|c|}{ External fruit color ${ }^{y}$} & \multicolumn{2}{|c|}{ Internal fruit color } \\
\hline & & $\mathrm{L}$ & Hue Angle & $\mathrm{L}$ & Hue Angle \\
\hline Solar Set & $4.1 \mathrm{a}^{\mathrm{x}}$ & $45.5 \mathrm{~d}$ & $48.2 \mathrm{~d}$ & 48.1 & $52.5 \mathrm{~b}$ \\
\hline Florida 91 & $3.1 \mathrm{~b}$ & $47.3 \mathrm{~b}$ & $50.8 \mathrm{~b}$ & 49.8 & $53.1 \mathrm{ab}$ \\
\hline Solar Fire & $3.0 \mathrm{~b}$ & $46.4 \mathrm{c}$ & $49.8 \mathrm{bc}$ & 48.6 & $52.2 \mathrm{~b}$ \\
\hline Florida 47 & $2.7 \mathrm{~b}$ & $48.2 \mathrm{a}$ & $52.4 \mathrm{a}$ & 49.6 & $54.5 \mathrm{a}$ \\
\hline & & & & NS & \\
\hline
\end{tabular}

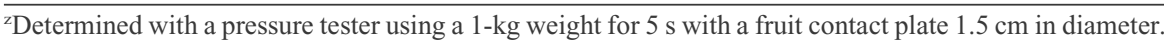
Pressure applied over a locule in the equatorial plane.

${ }^{y}$ Data acquired with a Minolta CR-300 chromameter. Higher L values indicate lighter color (value), lower hue angles indicate more red color (hue).

'Mean separation in columns by Duncan's multiple range test at $P \leq 0.05$.

wMeans in column not significantly different by Duncan's multiple range test at $P \leq 0.05$.

${ }^{\text {Ns Nonsignificant. }}$

Table 4. Water uptake for fruit of tomato genotypes immersed in water for 3 min. $^{\mathrm{z}}$

\begin{tabular}{llc}
\hline Cultivar & $\begin{array}{c}\text { Fruit } \\
\text { wt }(\mathrm{g})\end{array}$ & $\begin{array}{c}\text { Water uptake } \\
(\mathrm{g})\end{array}$ \\
\hline Solar Fire & $210 \mathrm{~b}^{\mathrm{x}}$ & $1.09 \mathrm{~b}$ \\
Fla. 7964 & $186 \mathrm{c}$ & $1.13 \mathrm{~b}$ \\
Florida 47 & $205 \mathrm{~b}$ & $2.02 \mathrm{a}$ \\
Florida 91 & $234 \mathrm{a}$ & $1.68 \mathrm{a}$ \\
Solar Set & $199 \mathrm{~b}$ & $0.76 \mathrm{c}$ \\
\hline
\end{tabular}

Cultivars were grown at Bradenton, Fla., in the fall of 2002. Water infiltration through the stem scar relates to soft rot susceptibility; less uptake means more tolerance to soft rot (Bartz, 1991).

${ }^{\mathrm{z}}$ For all columns, values equal the average of 10 fruit selected from harvest of four field plots.

${ }^{y}$ Data were adjusted for fruit size.

${ }^{x}$ Mean separation in columns by least square means test at $P \leq 0.05$.

water uptake (Smith, unpublished data) and thus is tolerant to bacterial soft rot. Fla. 7776 has shown graywall tolerance. Its main disorders are zippering and cuticle cracking.

\section{Availability}

'Solar Fire' has been released exclusively to Harris-Moran Seed Company. For research purposes, seed of 'Solar Fire' and Fla. 7776 will be available from Florida Foundation Seed Producers, PO Box 309, Greenwood, FL 32443 or through J.W. Scott.

\section{Literature Cited}

Bartz, J.A. 1991. Relation between resistance of tomato fruit to infiltration by Erwinia carotovora subsp. carotovora and bacterial soft rot. Plant Dis. 75:152-155.

Barten, J.H.N., J.W. Scott, and R.G. Gardner. 1994. Characterization of blossom-end morphology genes in tomato and their usefulness in breeding for smooth blossom-end scars. J. Amer. Soc. Hort. Sci. 119:798-803.

Scott, J.W. 2004. Fla. 7946 tomato breeding line resistant to Fusarium oxysporum f. sp. lycopersici races 1, 2, and 3. HortScience 39:440441.

Scott, J.W., P.H. Everett, H.H. Bryan, D.D. Gull, T.K. Howe, P.J. Stoffella, and R.B. Volin. 1985. Suncoast, a large-fruited home garden tomato. Florida Agr. Expt. Sta. Circ. S-322.

Scott, J.W., S.M. Olson, H.H. Bryan, T.K. Howe, P.J. Stoffella, and J.A. Bartz. 1989. Solar Set, a heat-tolerant, fresh market tomato hybrid. Florida Agr. Expt. Sta. Circ. S-359. 